\title{
Large scale northward expansion of warm water species Skeletonema tropicum (Bacillariophyceae) in China seas*
}

\author{
LIU Dongyan (刘东艳 $)^{1, * *}$, JIANG Jinjie (蒋金杰) $)^{1,2,3}$, WANG Yan (王妍) $)^{1,2,3}$, \\ ZHANG Yong (张永) $)^{1}$, DI Baoping (邸宝平) $)^{1}$ \\ ${ }^{I}$ Key Laboratory of Coastal Environmental Processes, Yantai Institute of Coastal Zone Research, Chinese Academy of Sciences, \\ Yantai 264003, China \\ ${ }^{2}$ South China Sea Institute of Oceanology, Chinese Academy of Sciences, Guangzhou 510301, China \\ ${ }^{3}$ Graduate University of Chinese Academy of Sciences, Beijing 100049, China
}

Received Nov. 30, 2011; accepted in principle Jan. 15, 2012; accepted for publication Feb. 2, 2012

(C) Chinese Society for Oceanology and Limnology, Science Press, and Springer-Verlag Berlin Heidelberg 2012

\begin{abstract}
Skeletonema tropicum is regarded as a species with an affinity to warm waters and it has never been reported in seas where temperatures drop below $11^{\circ} \mathrm{C}$ in winter. Previous studies in China reported that $S$. tropicum was restricted to subtropical and warm temperate seas (East and South China Seas), but the species was recently found during August cruises of 2009 and 2010 in Jiaozhou Bay, Yellow Sea, located several hundred kilometers to the north. Here, winter water temperatures often drop below $5^{\circ} \mathrm{C}$. Identification of S. tropicum was confirmed under light and scanning electronic microscopes and maximum cell abundance in Jiaozhou Bay was estimated as $1.73 \times 10^{4}$ cell/L. This record of S. tropicum in Jiaozhou Bay represents a significant northward expansion in the geographic range of the species. Ship ballast water was identified as a possible carrier of $S$. tropicum from southern places along Chinese coastline, and in addition, thermal pollution from local power stations and seawater desalination plants may provide suitable conditions for species over-wintering.
\end{abstract}

Keyword: biogeography; ballast water; thermal pollution; Skeletonema tropicum; Yellow Sea

\section{INTRODUCTION}

Diatoms, as one of the most important primary producers in marine ecosystem, are sensitive to changes in the environment and regarded as important indicators of water masses with different physical and chemical characteristics (Sarno et al., 2005). One of the most widespread genera of coastal marine diatoms is Skeletonema Greville, which contains approximately 20 species (Zingone et al., 2005). One of these species, Skeletonema tropicum CLEVE was first described by Cleve (1900) in samples from the tropical waters of the Atlantic Ocean and Caribbean coast of South America, but was later found along the coast of Eastern USA, the Atlantic side of Panama, Guyana and Surinam, the East and South China Seas (Cheng and Liu, 1992; Cheng et al., 2008), coastal Japan (Ueno, 1993), Gulf of Mexico (Castillo et al., 1995), Italy (Sarno et al., 2005), the Pacific side of Panama (Kooistra et al., 2008), southern Brazil (Bergesch et al., 2009) and India (Naik et al., 2010) (Fig.1).

On the basis of the geographic range of S. tropicum, it is regarded as a warm water species, restricted to tropical and subtropical areas. Hulburt and Guillard (1968) concluded that $S$. tropicum could not exist in regions where the seawater temperature drops below $13^{\circ} \mathrm{C}$ in winter; Ueno (1993) found that $S$. tropicum appeared in summer in the coastal waters of Japan but disappeared in early winter when the water temperature fell below $12^{\circ} \mathrm{C}$; the occurrence of $S$. tropicum in the Mediterranean Sea and coastal waters of Uruguay showed similar temperature range, winter surface seawater temperatures were not below $11^{\circ} \mathrm{C}$ (Kooistra et al., 2008; González-Piana and

\footnotetext{
* Supported by the National Natural Science Foundation of China (Nos. 40976097, 41006040), the Strategic Priority Research Program of Chinese Academy of Sciences (No. XDA05130703), and the Marine Special Scientific Fund for Non-profit Public Industry (No. 200805031) ** Corresponding author: dyliu@yic.ac.cn
} 


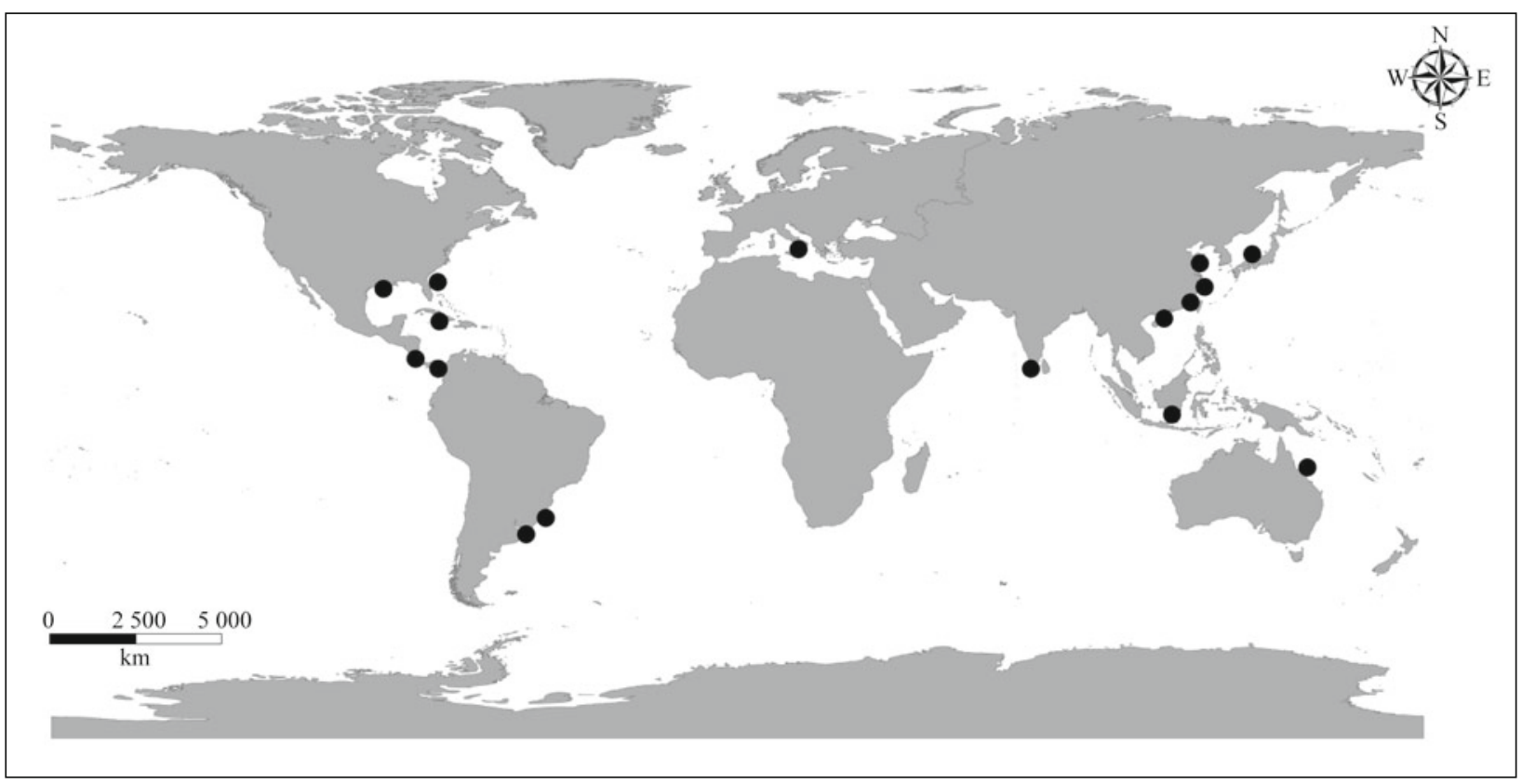

Fig.1 Global biogeography of Skeletonema tropicum

Ferrari, 2009). Yamada et al. (2010) found S. tropicum in Dokai Bay, Japan, where seawater temperatures ranged from $13.2^{\circ} \mathrm{C}$ to $27.2^{\circ} \mathrm{C}$. In China, $S$. tropicum has previously only been observed in the East and South China Seas, including Wenzhou, Xiamen, Daya Bay, Taiwan Straits and Haikou, which are all tropical or subtropical areas (Cheng and Liu, 1992; Cheng et al., 2008; Kooistra et al., 2008). The Yellow Sea is located in the northern region of the East China Sea, where the sea temperature can drop below $5^{\circ} \mathrm{C}$ in winter and increase to $27^{\circ} \mathrm{C}$ in summer. Despite numerous studies, $S$. tropicum was first found in the Yellow Sea in 2003, when Chen et al. (2007) isolated the cells of a $S$. costatum-like species from the Yellow Sea in October 2003 and grouped it as S. tropicum by the DNA sequence. However, it is uncertain whether the species had been transported into the Yellow Sea by currents or released with the ballast water of ships, or whether it had adapted to the environment of Yellow Sea, because Chen et al. (2007) only found it at one site and did not quantify the abundance.

During a scientific cruise in August 2009, a S. tropicum-like species was found in Jiaozhou Bay, a semi-enclosed basin in the western part of the southern Yellow Sea (Fig.2). Phytoplankton surveys of Jiaozhou Bay started in 1936, but S. tropicum had never previously been recorded in these surveys (Chin, 1936; Li and Huang, 1956; Qian and Wang, 1983; Guo, 1992; Liu, 2004; Yang et al., 2004; Li et al., 2005). Skeletonema costatum was the only species from genus Skeletonema previously recorded in the phytoplankton assemblages of Jiaozhou Bay. To confirm the occurrence of S. tropicum in the bay and distinguish it from $S$. costatum, the two species were isolated from the mixed phytoplankton samples under the light microscope (Olympus IX 81) and cultured for the observation of scanning electronic microscope (SEM). The abundance of the two species in surface seawater was counted during nine cruises of 2009 2011 for detecting the seasonal variations. Environmental factors that could have led to the occurrence of $S$. tropicum in Jiaozhou Bay were investigated including seawater temperature increases over the last few decades, thermal pollution and increased releases of ballast water. The hypothesis that $S$. tropicum could extend its biogeographic range in Chinese seas due to the impact of global warming and human activity in coastal waters is discussed.

\section{MATERIAL AND METHOD}

\subsection{Study area and sampling method}

Jiaozhou Bay $\left(35^{\circ} 55^{\prime}-36^{\circ} 18^{\prime} \mathrm{N}, 120^{\circ} 04^{\prime}-120^{\circ} 23^{\prime} \mathrm{E}\right)$ (Fig.2) is a semi-enclosed coastal bay, connected to the southern Yellow Sea, China through a narrow channel $(\sim 2.5 \mathrm{~km})$. It has a surface area of $390 \mathrm{~km}^{2}$ and an average water depth of 6-7 $\mathrm{m}$. Average seawater temperature is about $5.6^{\circ} \mathrm{C}$ in winter and 


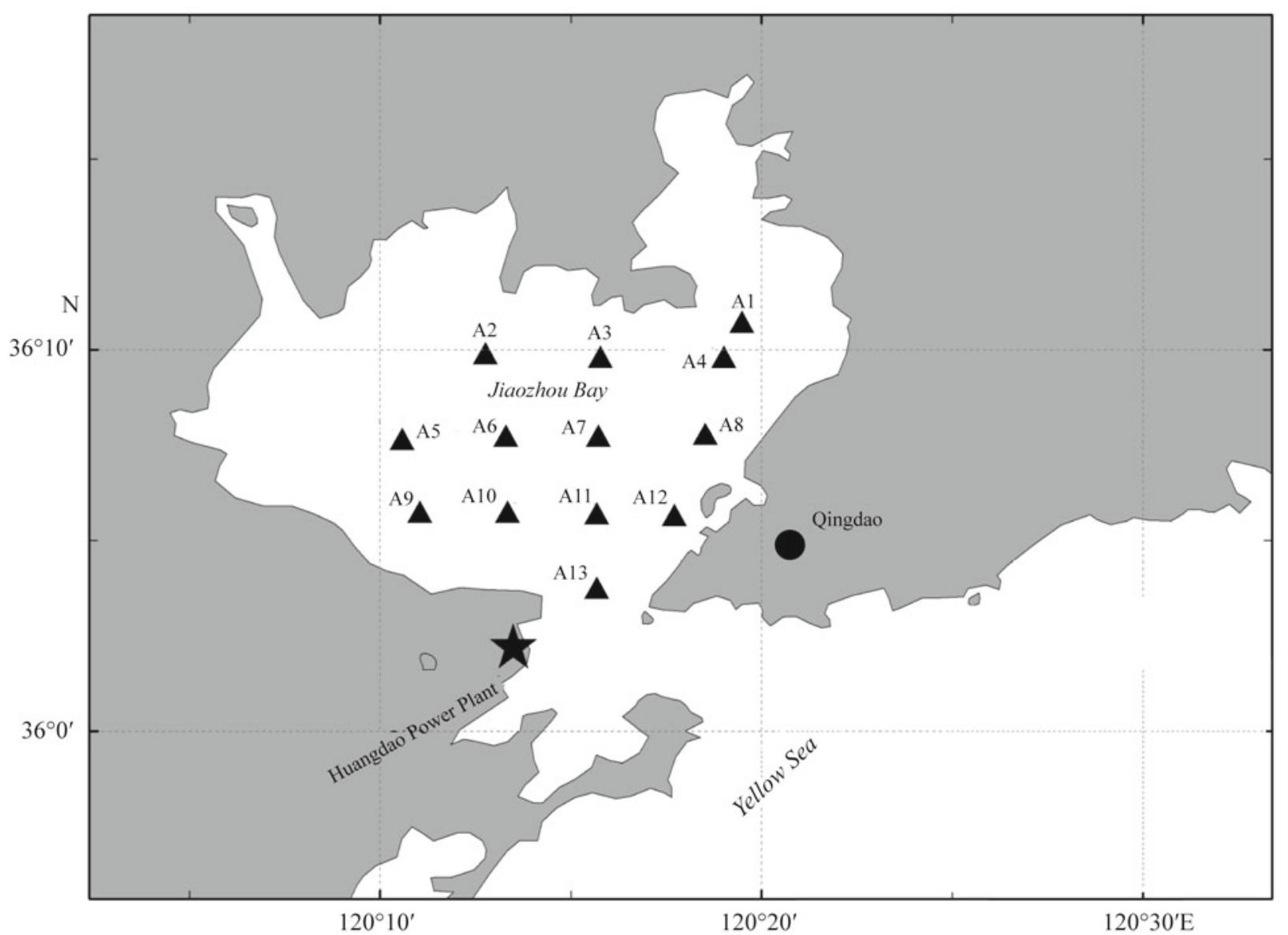

Fig.2 Sampling stations in the Jiaozhou Bay, Yellow Sea, China

$27.8^{\circ} \mathrm{C}$ in summer; the dramatic seasonal changes resulted from cold Siberian winds in winter and warm summer monsoons (Liu, 2006).

Phytoplankton samples were collected at 13 stations during nine cruises in May and August 2009, February, April, June, August, October 2010 and January and March 2011 (Fig.2). Seawater was collected at each station using a 5-L Niskin bottle, and a 500-mL sample was fixed with formalin (final concentration $5 \%$ ) and stored in polyethylene bottles for species identification and cell enumeration. The temperature and salinity in surface seawater were measured in-situ using a YSI 6920 multi-parameter water quality monitor.

\subsection{Species identification and cell numeration}

The morphology of $S$. tropicum-like species and S. costatum were observed and photographed under light microscopes (Olympus IX 81 and Olympus E-510 camera, respectively) at magnification of $400 \times$ and $1000 \times$. The ranges of cell sizes of S. tropicum- like species and $S$. costatum were estimated by measuring 100 cells of each sample, using digital camera software (IX2-BSW1.6). The two species were isolated from the mixed phytoplankton samples under the light microscope (Olympus IX 81) and cultured for the observation by scanning electronic microscope (SEM). The filtered samples were washed in distilled water, dehydrated in a series of $30 \%, 50 \%, 70 \%, 90 \%$, and $2 \times 100 \%$ ethanol, criticalpoint dried, and then sputter coated with goldpalladium. The chemical treated samples were observed under an SEM (JSM-5610LV) and images were recorded. Microstructures of the two species were compared to previous descriptions of S. tropicum and S. costatum (Ueno, 1993; Castillo et al., 1995; Sarno et al., 2005; Naik et al., 2010). Seawater $(25 \mathrm{~mL})$ of the mixed phytoplankton samples were taken and placed in a $25-\mathrm{mL}$ glass chamber for cell numeration. After 24-h settlement, cell abundances of the two species were counted under light microscope (Utermöhl, 1958). 


\section{RESULT}

\subsection{The morphological description of $S$. tropicum- like species and $S$. costatum}

Previous studies on Skeletonema genus show that the valve diameter, chloroplast number and process density of valves are key parameters to distinguish S. tropicum and S. costatum (Ueno, 1993; Castillo et al., 1995; Sarno et al., 2007; Yamada et al., 2010). $S$. costatum is characterized by cylindrical cellsforming chains in long tubular processes associated with a peripheral ring of fultoportulae, valve diameter 5-16 $\mu \mathrm{m}$ and each cell contains one to two chloroplasts (Table 1). In contrast, the valve diameter of $S$. tropicum has a wider range than S. costatum, and is commonly over $20 \mu \mathrm{m}$, which is rare for
S. costatum (Table 1). Our results show that the valve diameter of the $S$. tropicum-like species from the Jiaozhou Bay ranged 6.8-25.7 $\mu \mathrm{m}$, but that $S$. costatum only varied 4.3-15.1 $\mu \mathrm{m}$ (Table 1), suggesting that the two species found in the Jiaozhou Bay have different ranges of cell sizes. The number of chloroplasts is regarded as the most important characteristics to distinguish $S$. tropicum from S. costatum. S. costatum contains 1 or 2 chloroplasts in each cell, while $S$. tropicum usually has more than two chloroplasts and up to 15 chloroplasts in each cell (Table 1). In this study, 3-8 chloroplasts were found in each cell of the $S$. tropicum-like species (Fig.3a), and only 1-2 chloroplasts in each cell of $S$. costatum (Fig.3d). Again, this demonstrates a major difference between the two species from Jiaozhou Bay.

Table 1 Morphological comparison between Skeletonema tropicum and Skeletonema costatum

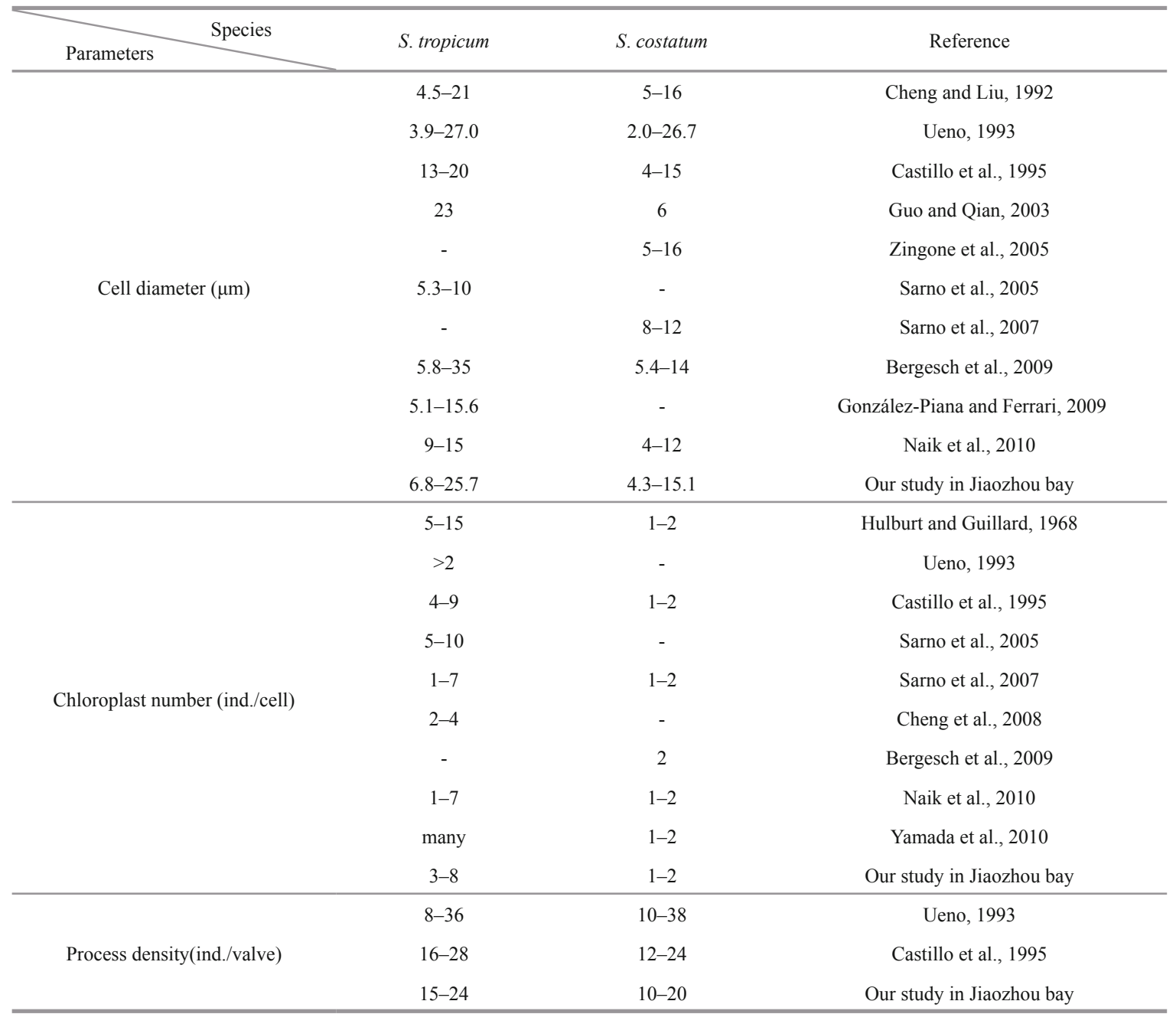




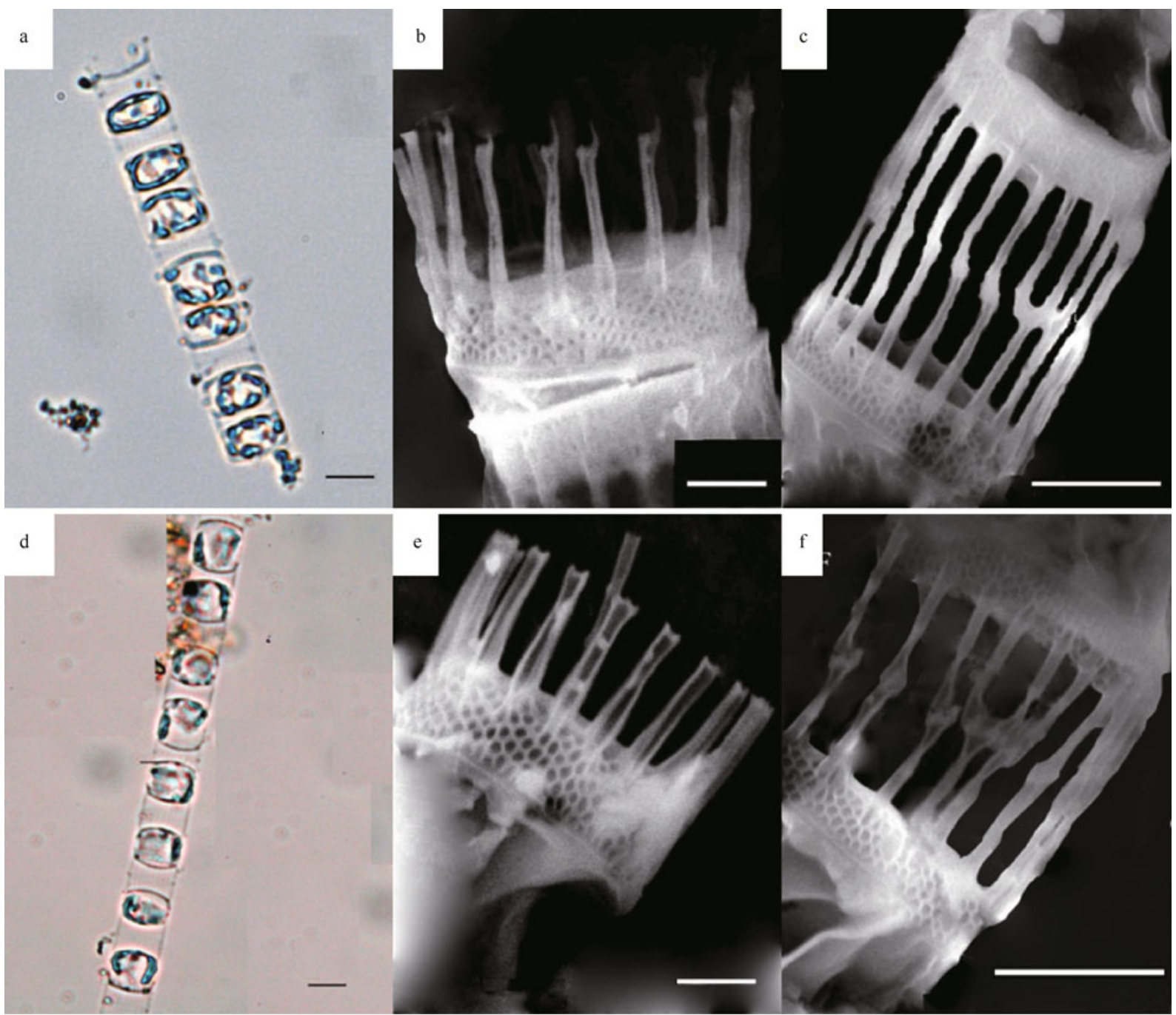

Fig.3 Observation of Skeletonema tropicum and Skeletonema costatum under LM and SEM

a. LM of S. tropicum (scale bar: $10 \mu \mathrm{m}$ ); b. SEM of S. tropicum showing terminal valve (scale bar: $2 \mu \mathrm{m}$ ); c. SEM of $S$. tropicum showing intercalary valve (scale bar: $5 \mu \mathrm{m}$ ); d. LM of $S$. costatum (scale bar: $10 \mu \mathrm{m}$ ); e. SEM of $S$. costatum showing terminal valve (scale bar: $2 \mu \mathrm{m}$ ); f. SEM of $S$. costatum showing intercalary valve (scale bar: $5 \mu \mathrm{m}$ ).

Cleve (1900) suggested that $S$. tropicum has more connecting processes when compared to $S$. costatum. However, more recent studies have found that the difference in the numbers of connecting processes was not always different between the two species and that this distinguishing characteristic should be used with care (Ueno, 1993). The numbers of connecting processes can vary with valve size, as larger valves usually have more processes. Thus, it is only the maximum number of processes/valve that is slightly higher for $S$. tropicum when compared to $S$. costatum (Table 1). In this study, 16-28 processes/valve were observed for S. tropicum (Fig.3b, c) and 12-24 processes/valve for $S$. costatum (Fig.3e, f). This indicates that there are only slight differences in these characteristics between the two species. However, the microstructure of the connecting processes of the two species is quite different. In SEM images, Naik et al. (2010) found that $S$. costatum has rimoportula processes and the end of the process was more like a protrusion; S. tropicum has fultoportula processes and the tips of process often showed a claw-like projection. In our study, using SEM, the $S$. tropicum-like species from the Jiaozhou Bay had fultoportula processes (Fig.3c) and the end of the processes had claw-like projections (Fig.3b). In contrast, S. costatum had rimoportula processes and the end of the processes was more like a protrusion (Fig.3e, f). Based on these 

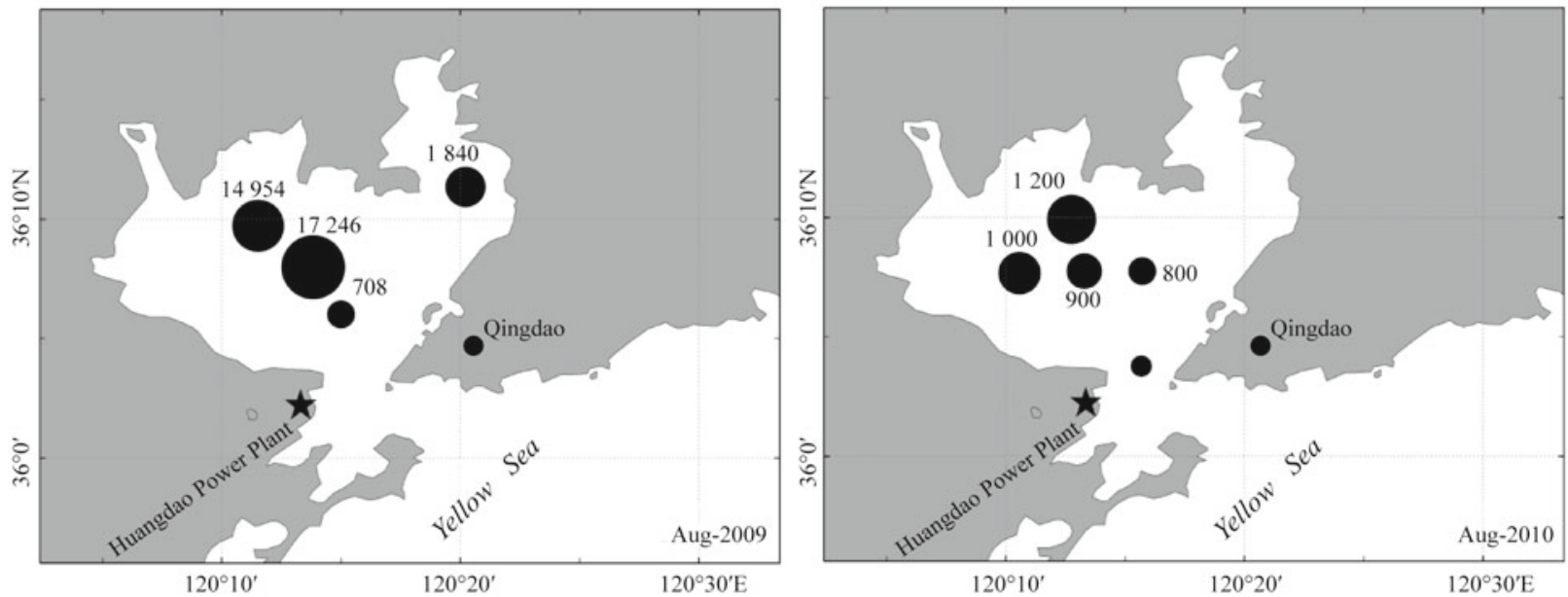

Fig.4 The occurrence and abundance of Skeletonema tropicum in the Jiaozhou Bay during the cruises of August 2009 and 2010

distinct taxonomic characteristics, the S. tropicumlike species in the Jiaozhou Bay was confirmed as $S$. tropicum.

\subsection{The cell abundance and distribution of $S$. tropicum in the Jiaozhou Bay}

The seawater samples collected from the Jiaozhou Bay in 2009, 2010, and 2011 were checked for the presence of $S$. tropicum and cell abundances of the species were recorded (Fig.4). S. tropicum was found in the cruises of August 2009 and August 2010 only, when sea temperature was about $25^{\circ} \mathrm{C}$ (Fig.5). $S$. tropicum was distributed mainly in the centre of the bay, and the cell abundance in August 2009 displayed higher values than in August 2010, with a maximum of $1.73 \times 10^{4} \mathrm{cell} / \mathrm{L}$ (Fig.4).

Sea temperature and salinity in the Jiaozhou bay determined the occurrence and abundance of S. tropicum. S. tropicum is known to grow well in warm waters. Ueno (1993) found that the cell abundance of $S$. tropicum dropped quickly in temperature below $25^{\circ} \mathrm{C}$, and disappeared when seawater temperature drop below $12^{\circ} \mathrm{C}$. During the sampling, the highest sea temperature in the Jiaozhou Bay was in August with a range of $24-26^{\circ} \mathrm{C}$, which met the temperature condition as $S$. tropicum required. However, the sea temperature was generally below $20^{\circ} \mathrm{C}$ in summer and autumn months (June and October) as observed in previous studies (Lin et al., 2005) and our cruise (Fig.5a). Thus, the growth of $S$. tropicum in Jiaozhou Bay decreased considerably after August, and result in low abundances, making the detection difficult. Castillo et al. (1995) found that S. tropicum grows optimally at salinity above $29^{\circ} \mathrm{C}$.
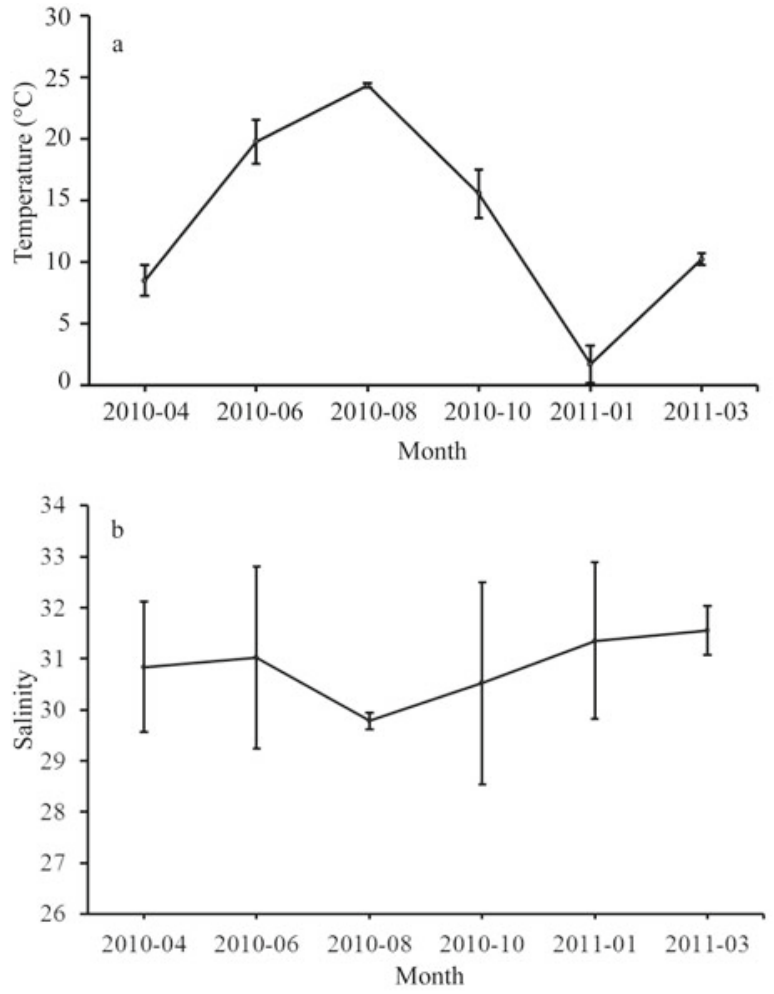

Fig.5 The annual variation of sea temperature and salinity in the Jiaozhou Bay during sampling period

The salinity in Jiaozhou Bay was above $29^{\circ} \mathrm{C}$ for most of the survey period (Fig.5b), which is good for the growth of S. tropicum.

\section{DISCUSSION}

In this study, the occurrence of S. tropicum in the Jiaozhou Bay was confirmed by investigating the 
morphology of $S$. tropicum-like species, by comparing this species to the co-occurring $S$. costatum and quantifying its abundance in August 2009 and 2010. Our findings show that the geographic distribution of $S$. tropicum along the China coastline had been expanded for many hundreds of kilometers. $S$. tropicum is regarded as a warm water species that could not survive water temperature below $13^{\circ} \mathrm{C}$ (Kooistra et al., 2008; González-Piana and Ferrari, 2009); it distributed only in the South China Sea and the East China Sea, and the first record of S. tropicum in China seas was in the Qiongzhou Straits in 1973, and then it was also found in Xiamen Harbor and Taiwan Straits (Cheng and Liu, 1992; Guo and Qian, 2003; Kooistra et al., 2008). Historical evidence suggests that $S$. tropicum is not a species that naturally occurred in the Jiaozhou Bay, located in the southern Yellow Sea of China where seawater temperature can increase to $26^{\circ} \mathrm{C}$ in summer and drop below $5^{\circ} \mathrm{C}$ in winter. The earliest phytoplankton investigation in the Jiaozhou Bay was carried out in 1936 (Chin, 1936); despite regular surveys, no S. tropicum-like species were recorded until Chen et al. (2007) isolated it from the Yellow Sea (outside of Jiaozhou Bay). Due to lack of detailed study, it is difficult to know whether this species was transported into the Yellow Sea by occasional currents or has been introduced through the release of ship ballast waters. Thus, it is important to consider how $S$. tropicum, a warm water species, has moved to the Jiaozhou Bay and adapted to local colder seawater temperatures.

Coastal currents were assumed to be one of possible transportation for the $S$. tropicum northward expansion. The Jiaozhou Bay is a semi-enclosed basin, connected with the southern Yellow Sea, China, through a narrow channel ( $2.5 \mathrm{~km}$ long). Water exchange between bay and ocean is controlled by the residual tidal currents of the Yellow Sea, which run in a clockwise circulation, moving up along the western coast and returning down in the eastern coast (Fig.2). The average residence time is about 52 days, ranging from less than 20 days near the bay channel to over 100 days in the northwest of the bay due to the limited tidal and near shore currents (Liu et al., 2004).

The increased ballast water brought by coastal ships was another possible carrier for the migration of S. tropicum from tropical to temperate seas. Qingdao Port is the largest port in Shandong Peninsula, and located in the east of the Jiaozhou Bay, facing into the Yellow Sea (Fig.2). Over the last few decades, the port has been developed quickly and currently deals with over 100 million tons of goods, and trades with 450 shipping ports in over 130 countries. Although no studies have been carried out in Qingdao Port, the introduction of alien species from ship ballast water has been suggested in Yantai Port (northern Yellow Sea) and Rizhao Port (southern Yellow Sea) in Shandong Peninsula (Li et al., 2006a, b). Thus, release of ballast water from cargo ships represents a possible pathway for the introduction of alien species (e.g., S. tropicum) to Jiaozhou Bay.

Climate is an important determinant for the geographic range of species (McCarty, 2001). Once introduced into the Jiaozhou Bay, S. tropicum needs a suitable sea temperature for growth and reproduction. A previous study in the Jiaozhou Bay region has suggested that average air temperatures have increased $0.56^{\circ} \mathrm{C}$ in summer and $2.62^{\circ} \mathrm{C}$ in winter since 1900 (Jiao, 2001); Liu (2006) also noted that the sea surface temperature in Jiaozhou Bay displays a slight increase since the $1960 \mathrm{~s}$, but not more than $2^{\circ} \mathrm{C}$. The survey data from our study and Jiang (2011) in the Jiaozhou Bay (Fig.5a) show that seawater temperatures can still drop below $5^{\circ} \mathrm{C}$ in winter. These data suggest that the sea temperature is not warm enough for S. tropicum to overwinter in the bay.

Compared with climate change, thermal pollution can significantly improve the sea temperature. In the late 1980s, Huangdao Power Plant was built up in the Jiaozhou Bay. Temperature difference between cooling water from Huangdao Power Plant and natural seawater ranged $5.5-11.5^{\circ} \mathrm{C}$, and the seawater temperatures in the outlet channel ranged $9.5-38^{\circ} \mathrm{C}$, which significantly affected the abundance of benthic macroalgae (Qian et al., 1993). The extent of the thermal pollution is approximately $0.25 \mathrm{~km}^{3}$ around the outlet, and the average increase of seawater temperature in winter in this zone was $4.82^{\circ} \mathrm{C}$ (Wang et al., 1998). During 2006-2010, the seawater desalination plants were built and linked to Huangdao Power Plant to increase energy efficiency. As a result, the thermal pollution-affected area increased significantly and transferred by tide current $(\mathrm{Wu}$ et al., 2008; Wang, 2009). Thus, it may be feasible that thermal pollution from Huangdao Power Plant and seawater desalination plants in the Jiaozhou Bay provide local conditions that allow populations of S. tropicum to survive over the winter.

In conclusion, the positive identification of S. tropicum in the Yellow Sea has extended the geographic range of this warm water species by several hundreds of kilometers, into temperate 
waters. It was assumed that the range extension of this species is through an accidental introduction of an alien species from the ballast water released by cargo ships travelling from further south. Thermal pollution from power stations and a desalination plant may then provide localized conditions that allow S. tropicum to overwinter in the Jiaozhou Bay. Additional research is required to investigate the possible links between this large extension in the range of $S$. tropicum along Chinese coastline, and the environmental impacts of ballast water releases and thermal pollution.

\section{ACKNOWLEDGEMENT}

We appreciate Dr. Zhe LIU and Dr. Min WANG at Ocean University of China for helping project in the Jiaozhou Bay.

\section{References}

Bergesch M, Garcia M, Odebrecht C. 2009. Diversity and morphology of Skeletonema species in southern Brazil, southwestern Atlantic Ocean. J. Phycol., 45: 1 348-1 352.

Castillo J A, Meave del Castillo M E, Hernández-Becerril D U. 1995. Morphology and distribution of species of the diatom genus Skeletonema in a tropical coastal lagoon. Eur. J. Phycol., 30: 107-115.

Chen GF, Wang G C, Zhang B Y, Fan X L. 2007. Morphological and phylogenetic analysis of Skeletonema costatum-like diatoms (Bacillariophyta) from the China Sea. Eur. J. Phycol., 42: 163-175.

Cheng J, Li Y, Liang J, Gao Y, Wang P, Kin-Chung H, Lin X. 2008. Morphological variability and genetic diversity in five species of Skeletonema (Bacillariophyta). Prog. Nat. Sci., 18: 1 345-1 355.

Cheng Z, Liu S. 1992. A taxonomy study of Skeletonema (Greville) from Xiamen Harbour. J. Xiamen Univ., 31: 295-297. (in Chinese with English abstract)

Chin T G. 1936. Occurrence and seasonal distribution of marine planktonic diatoms from Tsingtao and its vicinity. Philipp. Jour. Sci., 69: 437-454.

Cleve P T. 1900. Notes on some plankton organisms. Kungl. Svensk. Vet. Akad. Handl., 32: 1-53.

González-Piana M, Ferrari G. 2009. Skeletonema tropicum (Bacillariophyceae) present in Uruguayan southern coastal waters. IHERINGIA, Sér. Bot., 64: 145-149.

Guo Y. 1992. Phytoplankton in Jiaozhou Bay. In: Liu R Y ed. Ecology and Living Resources of Jiaozhou Bay. Science Press, Beijing. p.136-169. (in Chinese)

Guo Y, Qian S. 2003. Flora Algarum Marinarum Sinicarum (Tomus V) Bacillariophyta (No.1) Centricae. Science Press, Beijing. (in Chinese)

Hulburt E M, Guillard R L. 1968. The relationship of the distribution of the diatom Skeletonema tropicum to temperature. Ecology, 49: 337-339.

Jiang J. 2011. Tidal effects on diel variation of phytoplankton community structure in Jiaozhou Bay. Master degree thesis, Chinese Academy of Sciences.

Jiao N Z. 2001. Ecological Processes and Sustainable Development of Typical Coastal Water Ecosystems in China. Science Press, Beijing. (in Chinese)

Kooistra W H C F, Sarno D, Balzano S, Gu H, Andersen R A, Zingone A. 2008. Global diversity and biogeography of Skeletonema species (Bacillariophyta). Protist., 159: 177 193.

Li G G, Huang S. 1956. The original report of diatom seasonal variation study in Qindao inshore area. J. Shangdong Univ., 2: 119-143. (in Chinese)

Li Y, Li R X, Wang Z L, Zhu M Y, Sun P, Xia B. 2005. A preliminary study on phytoplankton community structure and its changes in the Jiaozhou Bay. Adv. Mar. Sci., 23: 328-334. (in Chinese with English abstract)

Li W, Sun J, Song S, Lei Z, Jia J, Wang D. 2006a. Phytoplankton community in Yantai harbor, Yantai anchorage and entry ship's ballast water, China. Trans. Oceanol. Limnol., 4: 70-77. (in Chinese with English abstract)

Li W, Sun J, Wang D, Jia J, lei Z, Wang X. 2006b. The characteristics of phytoplankton assemblage in Rizhao Harbor, Rizhao anchorage ground and entry ships ballast water, China. Mar. Sci., 30: 52-57. (in Chinese with English abstract)

Lin C, Ning X, Su J, Lin B Y, Xu B. 2005. Environmental changes and the responses of the ecosystems of the Yellow Sea during 1976-2000. J. Mar. Syst., 55: 223-234.

Liu D. 2004. Community structure succession study of phytoplankton and sediment diatom in Jiaozhou Bay. $\mathrm{PhD}$ thesis, Ocean University of China, P. R. China.

Liu Z. 2006. Abrupt changes of physical parameters in the Jiaozhou Bay and their potential environment impact. Postdoctoral Research Report, East China Normal University.

Liu Z, Wei H, Liu G, Zhang J. 2004. Simulation of water exchange in Jiaozhou Bay by average residence time approach. Est. Coast. Shelf Sci., 61: 25-35.

McCarty J P. 2001. Ecological consequences of recent climate change. Conserv. Biol., 15: 320-331.

Naik R K, Sarno D, Kooistra W H C F, Costa P M D, Anil A C. 2010. Skeletonema (Bacillariophyceae) in Indian waters: a reappraisal. Indian J. Mar. Sci., 39: 290-293.

Qian S, Chen H, Zhao X, Zhang Q. 1993. A study of the effect of thermal pollution on seaweeds. J. Ocean Univ. China, 23: 22-34.

Qian S, Wang X. 1983. The phytoplankton of the Jiaozhou Bay. J. Ocean Univ. China, 13: 39-56. (in Chinese)

Sarno D, Kooistra W H C F, Balzano S, Hargraves P E, Zingone A. 2007. Diversity in the genus Skeletonema (Bacillariophyceae): III. Phylogenetic position and morphological variability of Skeletonema costatum and Skeletonema grevillei, with the description of Skeletonema 
ardens sp. nov. J. Phycol., 43: 156-170.

Sarno D, Kooistra W H C F, Medlin L K, Percopo I, Zingone A. 2005. Diversity in the genus Skeletonema (Bacillariophyceae). II. An assessment of the taxonomy of S. costatum-like species with the description of four new species. J. Phycol., 41: 151-176.

Ueno S. 1993. On the occurrence of a tropical marine diatom Skeletonema tropicum in coastal waters of Japan with some morphological remarks. Bull. Plankton Soc. Japan., 39: 97-106.

Utermöhl H. 1958. Zur Vervollkommnung der quantitativen Phytoplankton-Methodik. Mitteilungen-Internationale Vereinigung fürLimnlogie, 9: 1-38.

Wang L, Sun Y, Zheng L. 1998. A three-dimentional prediction method for thermal diffusion. J. Ocean Univ. China, 28: 29-35.

Wang X. 2009. Study on the effect of brine on typical phytoplanktons in Jiaozhou Bay and the environmental capacity. Master thesis, Ocean University of China, P. R. China.

Wu Y, Mei N, Liang B. 2008. Study on transport and diffusion of concentrated and heated brine under the action of tide in Jiaozhou Bay. J. Ocean Univ. China, 38: 1 029-1 034.

Yamada M, Katsuki E, Otsubo M, Kawaguchi M, Ichimi K, Kaeriyama H, Tada K, Harrison P J. 2010. Species diversity of the genus Skeletonema (Bacillariophyceae) in the industrial harbor Dokai Bay, Japan. J. Oceanogr., 66: 755-771.

Yang D F, Wang F, Gao Z H, Cui W L, Huo S X. 2004. Ecological phenomena of phytoplankton in Jiaozhou Bay. Mar. Sci., 28: 71-74. (in Chinese with English abstract)

Zingone A, Percopo I, Sims P A, Sarno D. 2005. Diversity in the genus Skeletonema (Bacillariophyceae). I. A reexamination of the type material of Skeletonema costatum, with the description of S. grevillei sp. nov. J. Phycol., 41: 140-150. 